
Prieta Earthquake

he 1989 Loma Prieta earth-
quake ended decades of
tranquillity in the San Francisco Bay
region. It was a wakeup call to
prepare for the potentially even
more devastating shocks that are
inevitable in the future. Since 1989,
the work of the U.S. Geological
Survey (USGS) and other organiza-
tions has improved understanding of
the seismic threat in the Bay region,
promoted awareness of earthquake
hazards, and contributed to more
effective strategies to reduce
earthquake losses. These efforts
will help reduce the impact of future
large quakes in the San Francisco
Bay region.

Minutes before the scheduled start of the third game of the 1989 World Series in San Francisco, a magnitude 6.9 earthquake rocked the California coast from Monterey to San Francisco. Centered near Loma Prieta peak in the mountains south of San Jose, the quake

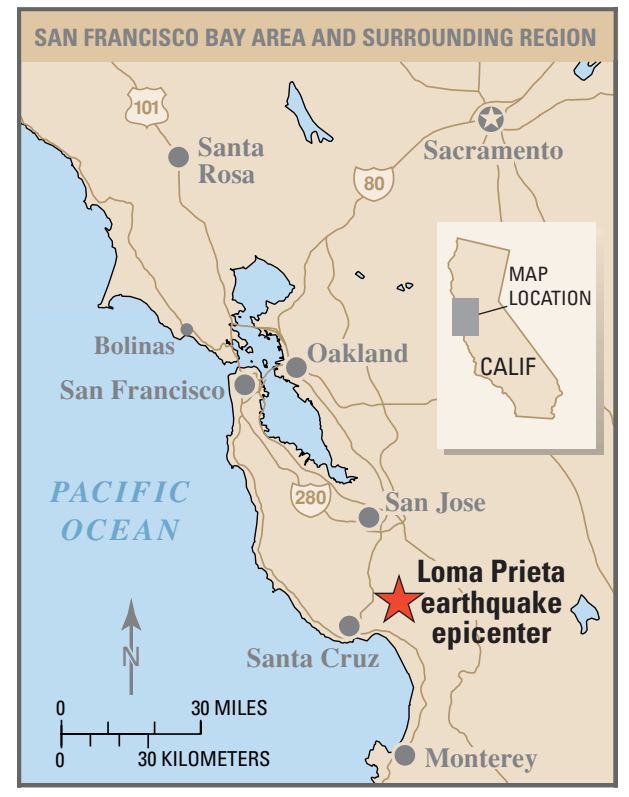

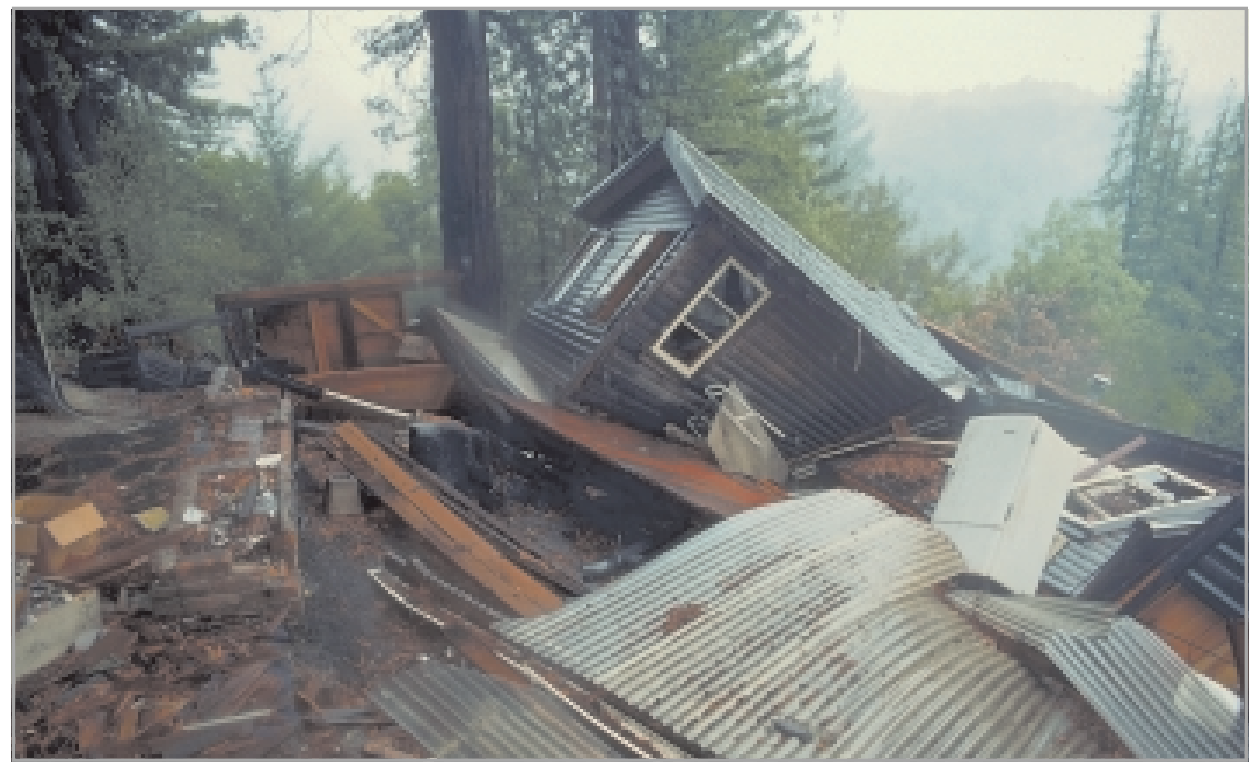

This house in the mountains north of Santa Cruz, California, was destroyed by the October 17, 1989, Loma Prieta earthquake. Shaking was very intense here, close to the epicenter of the magnitude 6.9 shock. However, heavily urbanized San Francisco and Oakland, more than 50 miles to the north, suffered more than $70 \%$ of the 63 deaths and the $\$ 6$ billion to $\$ 10$ billion in damage caused by the quake.

killed 63 people and caused an estimated $\$ 6$ billion to $\$ 10$ billion in property loss. It was the first large temblor to jolt the burgeoning urban region since the Great San Francisco Earthquake of 1906 (magnitude 7.8). Although the Loma Prieta earthquake struck on the periphery of the region-more than 50 miles from San Francisco and Oakland-it exposed the vulnerability of the region to enormous losses in future quakes, some of which will be larger and closer to its urban core.

Since the Loma Prieta shock, the U.S. Geological Survey (USGS) and cooperating organizations have intensified efforts to understand earthquake hazards and apply this new knowledge to reducing future losses. Greater attention has been focused on the Nation's urban regions threatened by strong earthquakes, because these areas have the most people at risk, the largest inventory of structures, and the densest and most complex infrastructure. Communication of earthquake-hazard information to the public and to those in business and government responsible for decisions and actions has also been strengthened. The following paragraphs highlight advances and accomplishments of these efforts in the San Francisco Bay region since the 1989 earthquake.

\section{Earthquake probabilities}

The year after the 1989 Loma Prieta shock, a panel of scientists reassessed the earthquake threat to the San Francisco Bay region. Their conclusions were published in the USGS report "Probabilities of Large Earthquakes in the San Francisco Bay Region, California.” They projected 2-in-3 odds for one or more destructive earthquakes (magnitude 7 or larger) to strike the Bay region in the period 1990 to 2020.

Studies made since that 1990 report have added much new information for determining earthquake probabilities. Geologists have uncovered new evidence for the dates and amounts of slip of prehistoric earthquakes on the Hayward, San Andreas, and other active Bay region faults and for the amounts of movement on those faults over past millennia. Seismologists have reassessed the early earthquake history of the region. Many strong earthquakes occurred in the several decades before the 1906 San Francisco earthquake, whereas in the decades since then, the region has been rather quiet seismically. Seismologists attribute this to the 1906 quake temporarily relieving most of the stress in crustal rocks in the Bay region. Using satellite-based techniques, geophysicists have gained a better picture of the continuous motions of crustal plates that cause 


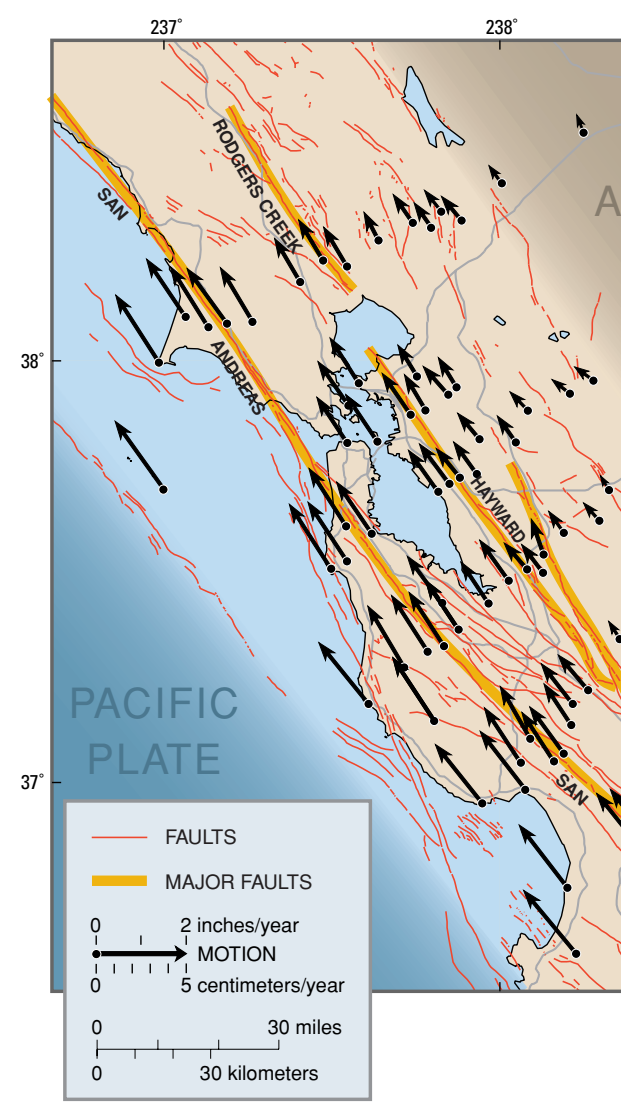

faults to accumulate stress and rupture in earthquakes.

These data are incorporated in a new USGS report that estimates the locations, sizes, and probabilities of damaging Bay region earthquakes during the next 30 years (2000 to 2030). This new assessment will help business, government, and the public assign priorities for strengthening weak structures and for other measures to reduce earthquake impacts.

\section{Ground shaking and building codes}

Most loss of life and damage to property during an earthquake stems from strong ground shaking. Hence, accurate assessment of the shaking hazard is fundamental to the design and the
The San Francisco Bay region lies on the boundary zone between two of the major tectonic plates that make up the Earth's outer shell. The continuous motion between the Pacific and North American Plates, distributed across this zone, is monitored by geophysicists using the satellitebased Global Positioning System (GPS). Arrows on this map depict recent (mid to late 1990's) rates of movement, relative to the interior of the North American Plate, of reference markers anchored in rock or deep in solid ground. This relentless motion of the plates strains the crustal rocks of the Bay region, storing energy that eventually will be released in earthquakes. During the time represented in this diagram, most of the faults in the Bay region have been "locked," not producing earthquakes.

building of structures that can resist earthquakes In 1996, the USGS and the California Division of Mines and Geology (CDMG) produced a set of State-wide shaking-hazard maps based on current knowledge of more than 200 active faults and of the historical earthquake record. These maps depict geographic variations in the likely maximum severity of shaking to be experienced within a 50-year period. Maps for various frequencies of ground vibration are included because various frequencies of shaking affect buildings of different heights differently. These maps are a principal foundation element for the seismic provisions of a new national building code to become available in 2000. In parts of the San Francisco Bay region, requirements under the new code will differ significantly from those under earlier codes.

During the Loma Prieta earthquake, the USGS and CDMG obtained the first set of re-

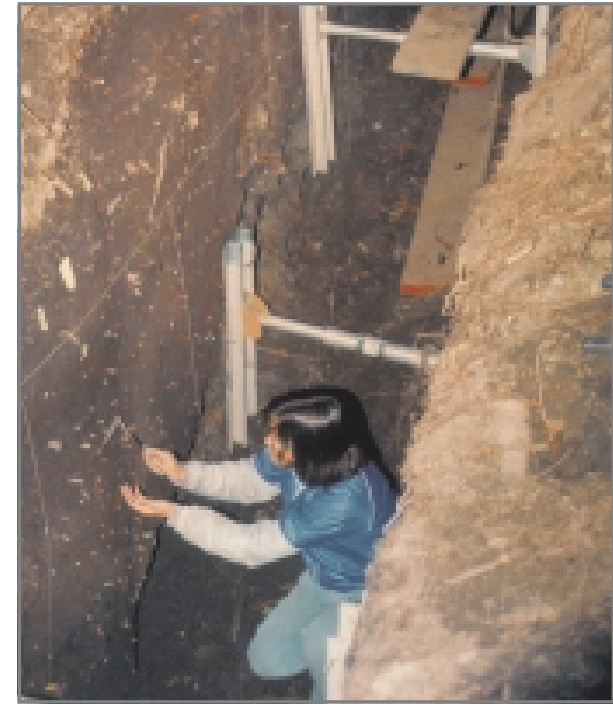

In this deep trench dug across the San Andreas Fault near Loma Prieta peak, California, U.S. Geological Survey scientists identified soil layers disrupted by the last great earthquake before the 1906 San Francisco earthquake (magnitude 7.8). Radiocarbon dating of plant remains from the layers in the trench indicates that the earlier quake occurred about A.D. 1600, before written historical records were kept in California.

cordings of damaging levels of shaking on a wide variety of geologic materials, including soft, unconsolidated sand and clay. These records clearly document that ground shaking is much more violent on the soft sediments around the Bay margins than on bedrock, confirming previous USGS projections. Most importantly, these records provided a firm basis for revising building codes to more fully reflect the need for extra strength in structures built on soft ground. This improved understanding of the shaking hazard on soft ground has led to significant changes in provisions of the forthcoming national building code and to recommended changes to the national highway-bridge code. Because earthquake-resistant design and construction are essential to reducing earthquake losses, these code revisions are a major step toward greater earthquake safety.

The part of the Cypress freeway structure in Oakland, California, that stood on soft mud (dashed red line) collapsed in the 1989 Loma Prieta earthquake, killing 42 people. Adjacent parts of the structure (solid red) that were built on firmer ground remained standing. Seismograms (upper right) show that the shaking was especially severe in the soft mud. (Photo, Lloyd S. Cluff.)
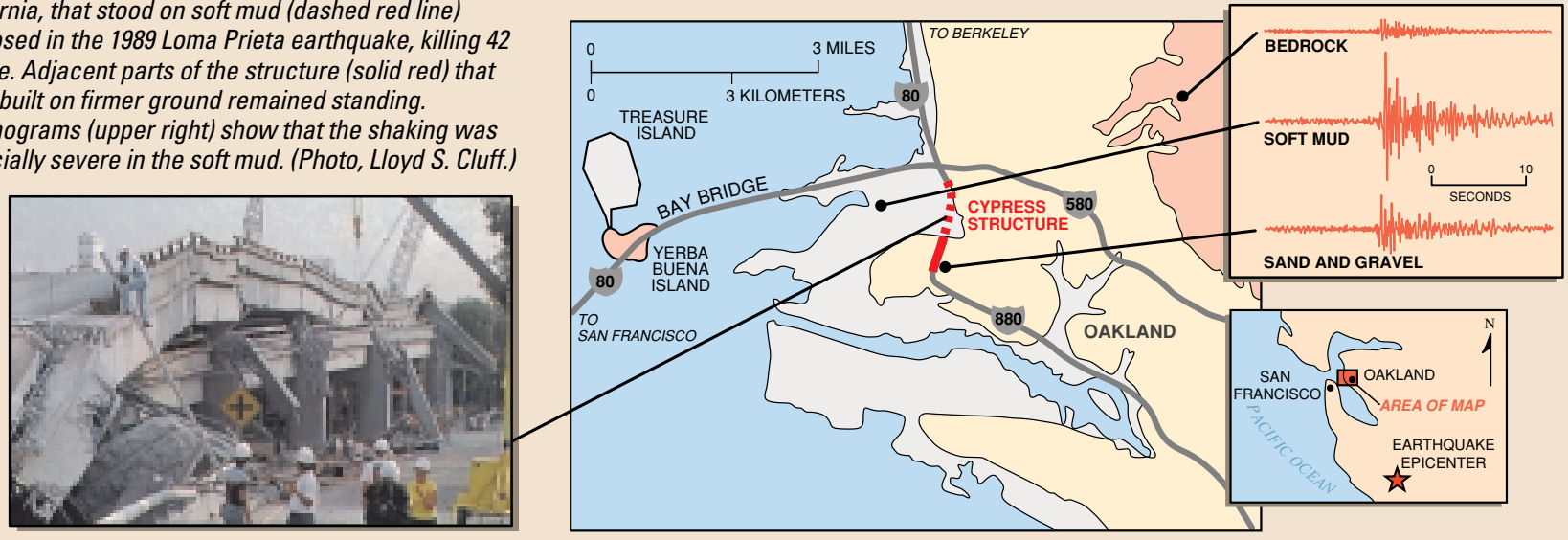


\section{Ground failure}

Another earthquake hazard, which locally can be more damaging than shaking alone, is failure of the ground. Rocks may fall from cliffs, steep slopes may slide, earth may flow downslope, and even flat ground may crack and tilt. When shaken strongly, unconsolidated sandy deposits that are saturated with water can liquefy and form a slurry. This process is called "liquefaction." Slurries have little ability to support the weight of man-made structures or to resist flowing downslope, even on nearly flat ground. Liquefaction may result in sinking, tilt, distortion, or destruction of buildings and bridges, rupture of underground gaslines and water mains, and cracking and spreading of the ground surface.

In the Loma Prieta earthquake, loosely compacted geologic deposits and artificial fills liquefied at many locations around the margins of San Francisco and Monterey Bays and in adjacent river beds. Had the quake been larger or nearer to the heavily developed margin of San Francisco Bay, the damage from liquefaction would have been far greater. The USGS and the Pacific Gas and Electric Company (PG\&E) initiated a cooperative research and development agreement in 1997, in part because liquefaction can threaten gas pipelines. As part of this effort, a sophisticated mechanized earth probe is being used to determine whether young sand deposits ringing the Bay may liquefy during strong shaking. The results of these field tests will be used to prepare a new, detailed set of liquefaction-hazard maps for the Bay region.

\section{Earthquake scenarios}

Although scientists cannot predict the time of destructive earthquakes, they can project the effects of a postulated temblor and, together with engineers, the expected property damage and loss of life. Emergency-response managers, government agencies, corporate planners, and private citizens can use such projections to reduce risk of losses and to facilitate response and recovery after a large quake. USGS scientists are working with numerous agencies and organizations to estimate the impact of future earthquakes at both regional and national scales.

In 1995, the USGS and the Association of Bay Area Governments (ABAG) collaborated to produce maps of ground-shaking intensity for several possible earthquake scenarios. The maps depict how shaking intensity depends on distance from the earthquake source and on local ground conditions. Maps of individual cities are accessible on the Internet (http://www.abag.ca.gov/bayarea/eqmaps/). These maps show the estimated shaking intensities superimposed on street networks that allow residents to locate their neighborhoods and workplaces.

On a national scale, in 1997, the Federal Emergency Management Agency (FEMA) released HAZUS, a geographically oriented, PC-based software package that estimates losses from natural hazards. Developed under contract by the National Institute for Building Sciences, HAZUS is intended to
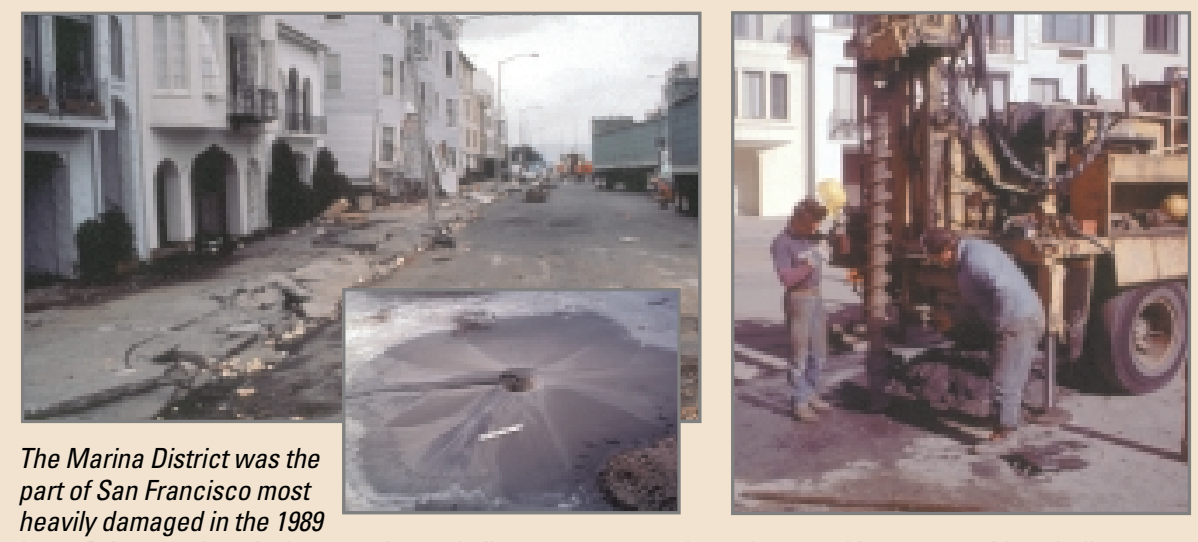

heavily damaged in the 1989

Loma Prieta earthquake because it was built on uncompacted, sandy ground in an area with a shallow water table. These conditions caused shaking to be amplified and some areas of ground to "liquefy." Along this street in the District, shaking collapsed the first story of an apartment house and liquefied the ground beneath the sidewalk, causing it to buckle. Inset photo shows a "sand volcano" created when liquefied sand "erupted" to the surface. In the weeks following the quake, the U.S. Geological Survey drill rig shown at right was used to gather subsurface samples so that the causes of liquefaction could be better understood. be a national standard. It is available to all levels of government (Federal, State, and local) and the private sector for estimating potential losses and promoting actions to reduce future risk to people and property. In its initial development, HAZUS has focused on earthquake hazards and risks. USGS scientists contributed critical data and technical guidance to the development and testing of the software package.

\section{Seismic-hazards mapping}

Since the late 1960's, the USGS and its many cooperators have pioneered innovative methods for evaluating, mapping, and quantifying geologic hazards related to earthquakes.
These advances have stimulated State and local government initiatives to identify local hazards and require that they be taken into account in decisions about land use and development.

An example is the California Seismic Hazards Mapping Act of 1990, passed by the California Legislature in the wake of the Loma Prieta earthquake. Intended to assist cities and counties in protecting public health and safety, the Act established a State-wide mapping program to identify areas subject to violent shaking and ground failure. The scientific foundation for the Act came from knowledge and understanding developed by the USGS, CDMG, and cooperating research institutions and consulting firms. In preparing the official

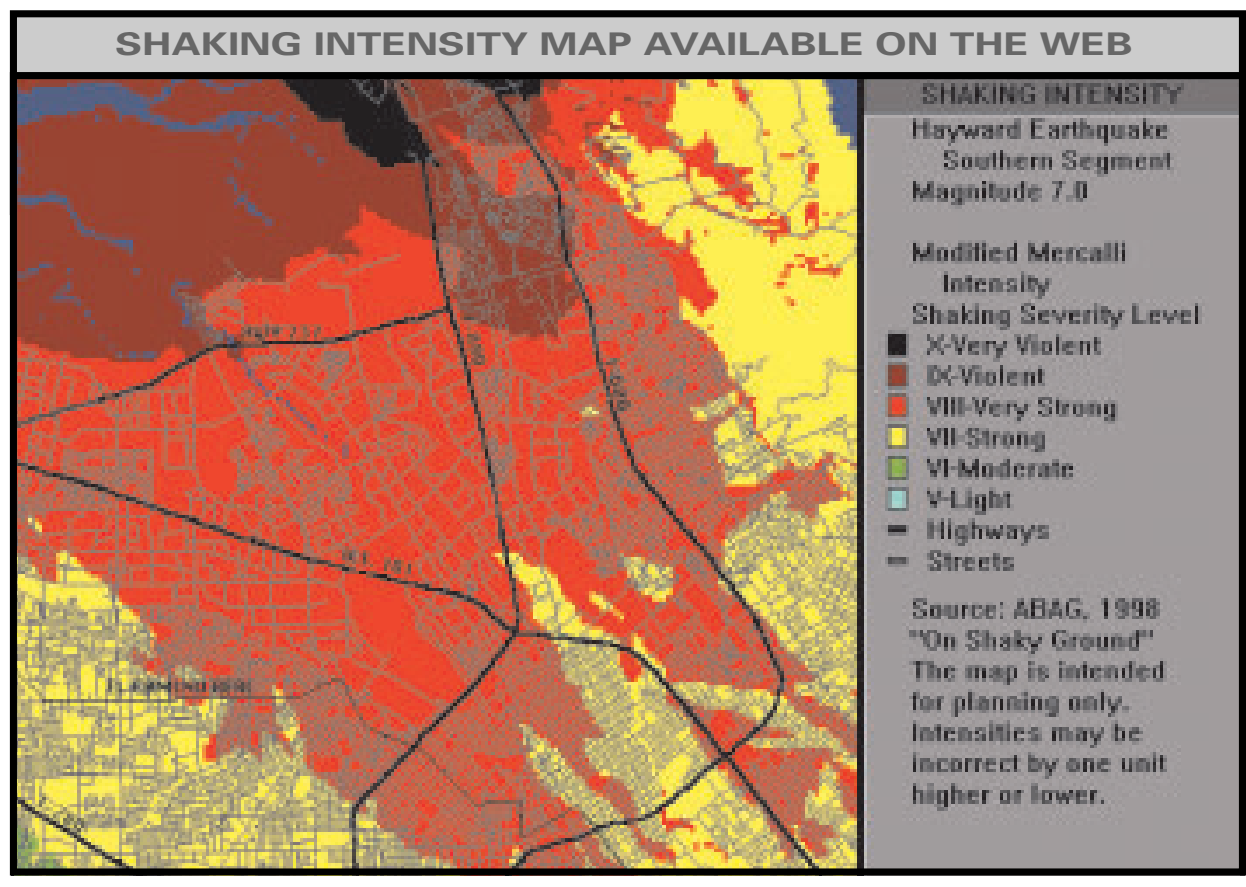

Residents of the San Francisco Bay region can view maps of expected ground-shaking intensity for their communities for several possible large earthquakes. These maps, produced by the Association of Bay Area Governments (ABAG) and the U.S. Geological Survey, are available online at http://www.abag.ca.gov/bayarea/eqmaps/. This map of north and central San Jose is for a magnitude 7.0 shock on the southern segment of the Hayward Fault (northeast is at top of map). 
maps of seismic-hazard zones, CDMG incorporates the latest information on ground properties, faults, and earthquake potential in the State.

\section{Earthquake information}

Modern computer technology allows wide access to authoritative information about an earthquake immediately after its occurrence. Computers at the USGS and the University of California at Berkeley (UCB) have for some years automatically posted information for northern California shocks on the World Wide Web.

In 1996, when a magnitude 4.7 shock struck the San Francisco Bay region, the great demand for information overwhelmed the capacity of the Web site. The site has been continually upgraded, and its capacity expanded. Currently, a location map is usually posted on the site within 1 minute of a widely felt earthquake, and the magnitude within 5 minutes (http://quake.usgs.gov/recenteqs/). When a magnitude 5.0 quake occurred beneath Bolinas in mid-August 1999, more than 30,000 users were able to access this Web site in the first hour after the quake struck.

The USGS, CDMG, UCB, and PG\&E are cooperating to add information on the severity of ground shaking to the Web site. As of fall 1999, maps showing the pattern of shaking measured across the region can be posted within tens of minutes of broadly felt earthquakes.

Quick access to information on ground shaking will be of particular value in the Bay region, where the wide variety of geologic materialsfrom hard bedrock to soft clay-causes large differences in shaking intensity. This information will help emergency-response officials to identify locations where damage and need are likely to be greatest. In past quakes, identifying such locations has too often been delayed by disrupted communications. As a result, the initial picture of the earthquake's effects has often been seriously incomplete.

\section{Earthquake preparedness}

The Loma Prieta earthquake was a painful reminder of the need to be aware of natural hazards and to take steps to minimize the potential impact of threatening events. To reduce losses from natural disasters, in 1997 FEMA initiated "Project Impact: Building a Disaster Resistant Community." A pilot effort under this program of public/private partnerships is being conducted in the city of Oakland.

Contributing expertise to this effort, the USGS is pursuing a range of projects focused on earthquake hazards threatening the Oakland community:

- Demonstrating an economical, automated system for rapidly mapping the intensity level of strong shaking throughout Oakland minutes after a large earthquake occurs-Maps are derived from measurements of the ground shaking at numerous points throughout the city and from knowledge of how ground type varies with location.

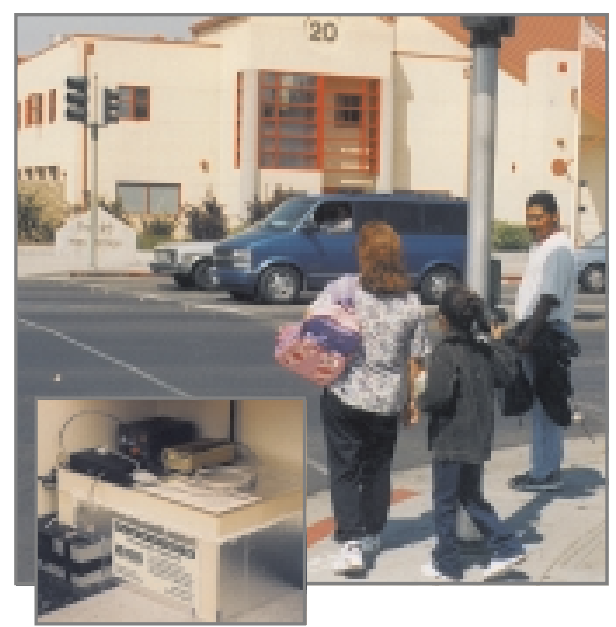

The U.S. Geological Survey, as part of a public-private partnership, operates a network of seismic instruments at many sites in Oakland, California. The instruments, such as this one (see inset) in Fire Station 20, measure and report levels of ground shaking. This network will help guide emergency response to areas most in need in future quakes.

- Probing natural and filled ground at the Port of Oakland-These studies investigate how much the shaking of the underlying bedrock would be amplified by the overlying soil during an earthquake and whether the ground would liquefy.

- Determining whether slopes within the Oakland Hills are likely to fail by landsliding during earthquake shaking-Computer analyses of the stability of slopes take into account possible levels of shaking, topography, and strength of slope materials.

\section{Communication}

Since the 1989 Loma Prieta earthquake, the USGS has increased efforts to communicate earthquake-hazard information and research findings to a broad audience. In 1990, the USGS and several cooperators, with financial support from the American Red Cross and the United Way, produced a popular educational pamphlet, "The Next Big Earthquake in the Bay Area May Come Sooner Than You Think.” The pamphlet was published in English, Spanish, Chinese, and Braille, and as an audio tape through Recordings for the Blind. More than 2 million copies were initially distributed as Sunday newspaper inserts. Because of continuing demand, the pamphlet was reprinted in 1994, and a total of nearly 5 million copies have now been distributed. The pamphlet has been emulated in other highly active seismic regions-southern California, the Cape Mendocino region of northern California, the Puget Sound region of Washington, and southern Alaska.

On another front, the USGS joined in partnership in 1997 with the Institute for Business and Home Safety (IBHS), an affiliation of insurance and reinsurance companies. The mission of the institute is to reduce deaths, injuries, property damage, economic losses, and human suffering caused by natural disasters. To increase awareness and understanding within the insur- ance sector of earthquake threats, the USGS and IBHS have convened annual workshops on earthquake and insurance issues and have prepared a monograph on these topics.

The USGS is also taking other steps to bring earthquake information to the public. A 1990 USGS video, "When the Bay Area Quakes," vividly explains the cause and effects of the Loma Prieta shock. USGS Circular 1130, "Look Before You Build," published in 1995, shows how geologic information can contribute to safer land development in quake-prone areas. A series of 13 USGS Fact Sheets, published from 1995 to 1997 under the overall title "Reducing Earthquake Losses Throughout the United States," explains earthquake hazards in nontechnical language. In addition to posting information on quake activity on the Web, the USGS routinely provides such data to news organizations. Maps based on these data appear regularly in the media. In other efforts to directly disseminate information and answer the public's questions about earthquakes, USGS scientists participate in media events, conferences, and quake-preparedness fairs, and visit local schools.

Earthquakes remain a serious threat to the San Francisco Bay region. Large quakes will certainly shake this urban region in coming decades, but the impacts of these events can be reduced. Continuing advances in science and engineering and improved practices in construction, land use, emergency response, and disaster recovery will offer new avenues to limit losses and reduce impacts of future shocks.

The efforts highlighted here are part of the USGS Earthquake Hazards Program — a key element of the National Earthquake Hazards Reduction Program. In the ongoing efforts to safeguard lives and property from future earthquakes, the USGS program not only involves USGS scientists but also engages expertise and talent in academia, private companies, and State and local governments.

Robert A. Page, Peter H. Stauffer, and James W. Hendley II Graphic design by

Sara Boore, Susan Mayfield, and Michael F. Diggles

COOPERATING ORGANIZATIONS

Association of Bay Area Governments California Division of Mines and Geology

California Governor's Office of Emergency Services City of Oakland Office of Emergency Services Federal Emergency Management Agency Geomatrix Consultants Inc.

Institute for Business and Home Safety

National Institute for Building Sciences

Pacific Gas and Electric Company

San Francisco State University Stanford University

University of California at Berkeley

University of California at Santa Cruz

URS Greiner Woodward Clyde Federal Services William Lettis \& Associates

Many other institutions, organizations, and firms

For more information contact:

Earthquake Information Hotline (650) 329-4085

U.S. Geological Survey, Mail Stop 977

345 Middlefield Road, Menlo Park, CA 94025 http://quake.usgs.gov/ 